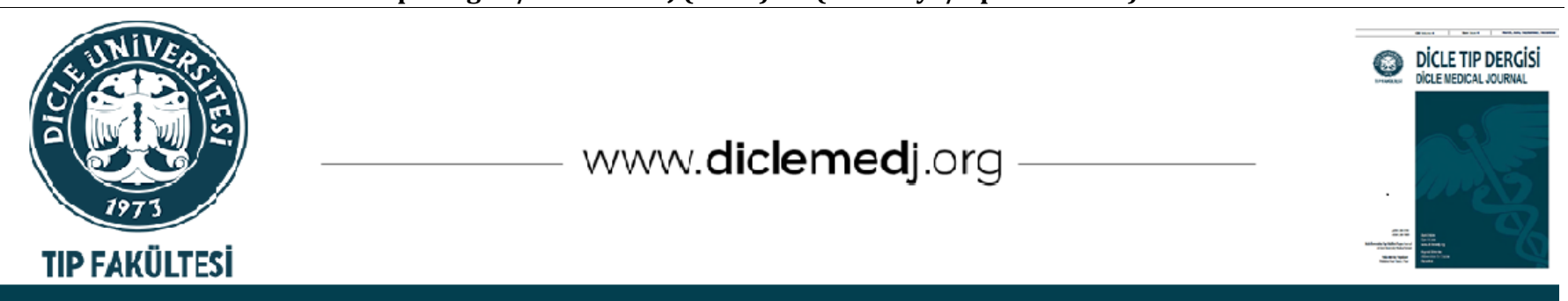

Derleme / Review

\title{
COVID-19 ve Yoğun Bakım Süreci
}

\author{
Ali Kemal Kadiroğlu ${ }^{1} 1$ \\ 1 Dicle Üniversitesi Tıp Fakültesi İç Hastalıkları AD / Erişkin Yoğun Bakım BD, Diyarbakır, Türkiye \\ Geliş: 01.08.2021; Kabul Tarihi: 29.09.2021
}

\section{$\ddot{\mathbf{O z}}$}

Akut solunum yetmezliği ve hemodinamik kararsızlıkla beraber, dispne ve solunum güçlüğü, solunum sayısı $\geq 28$ /dakika, 5 litre/dakika ve üstünde nazal oksijen desteğine rağmen oksijen satürasyonu <\%93, 5 litre/dakika ve üstünde nazal oksijen desteğine rağmen parsiyel oksijen basıncl $<60 \mathrm{mmHg}$, PaO2/FiO2 $<300$ olanlar Covid-19 pnömonili kritik hastadır ve yoğun bakım ünitesinde tedavi ve takip edilmelidir. Bu hastalar yoğun bakıma kabul edildikten sonra klinik, laboratuvar ve görüntüleme bulguları yönüyle detaylı değerlendirilmelidirler.

Öncelikle geleneksel oksijen destek tedavileri(nazal kanül, yüz maskesi ve rezervuarlı maske) başlatılmalı sonuç alınamazsa yüksek akımlı nazal kanülasyon uygulanmalı, bu yöntem de başarısız olursa non-invaziv mekanik ventilasyon başlanmalıdır. Oksijen destek tedavisi yapılmasına rağmen hedef oksijen saturasyonu, solunum sayısı ve optimal solunum fizyolojisine ulaşılamadıysa bu durumda vakit kaybetmeden entübasyon ile mekanik ventilasyon destek tedavisine geçilmelidir. Hastalar uygun olduğunda da standart weaning süreci uygulanmalıdır.

Covid-19 pnömonili hastalarda mortalite, gelişen ARDS zemininde ve ilave negatif prognostik faktörlerle $\% 25$-50 oranında gerçekleşmektedir.

Anahtar kelimeler: Covid-19, pnömoni, Oksijen tedavisi, NIMV, MV, weaning

DOI: 10.5798/dicletip.1004071

Yazışma Adresi / Correspondence: Ali Kemal Kadiroğlu, Dicle Üniversitesi Tıp Fakültesi İç Hastalıkları AD / Erişkin Yoğun Bakım BD, Diyarbakır, Türkiye 21100 e-mail: akkadiroglu63@gmail.com 


\title{
COVID-19 and Intensive Care Process
}

\begin{abstract}
The patient with acute respiratory failure and hemodynamic instability, dyspnea and respiratory distress, respiratory rate $\geq 28 /$ minute, oxygen saturation $<93 \%$ despite nasal oxygen support of 5 liters/minute and above, partial oxygen pressure $<60 \mathrm{mmHg}$ despite nasal oxygen support of 5 liters/minute and above, and Pa02/FiO2 < 300 are critically ill with Covid-19 pneumonia and should be treated and followed up in the intensive care unit. After these patients are admitted to the intensive care unit, they should be evaluated in detail in terms of clinical, laboratory and imaging findings.

First of all, traditional oxygen support treatments (nasal cannula, face mask, mask with reservoir) should be started, if no results are obtained, high flow nasal cannulation should be applied, and if this method fails, noninvasive mechanical ventilation should be started. If the target oxygen saturation, respiratory rate and optimal respiratory physiology could not be reached despite the oxygen support treatment, intubation and mechanical ventilation support treatment should be started without wasting time. The standard weaning process should also be applied when patients are eligible.

Mortality in patients with Covid-19 pneumonia occurs at a rate of $25-50 \%$ on the background of developing ARDS and with additional negative prognostic factors.
\end{abstract}

Key words: Covid-19, pneumonia, Oxygen therapy, NIMV, MV, weaning.

\section{Giriş}

Yoğun Bakım Endikasyonu Olan COVID-19 Pnömonili Kritik Hasta Tanımı

Akut solunum yetmezliği ve hemodinamik kararsızlığı olan aşağıdaki kriterlere sahip kritik hastalar yoğun bakım ünitesinde tedavi ve takip edilmelidirler.

- Dispne ve solunum güçlüğü, Solunum sayısı $\geq 25 / \mathrm{dk}, 5 \mathrm{lt} / \mathrm{dk}$ ve üzerinde nazal oksijen desteğine rağmen oksijen satürasyonu \%93'ten küçük ise, $5 \mathrm{lt} / \mathrm{dk}$ ve üzerinde nazal oksijen desteğine rağmen parsiyel oksijen basıncı 60 mmHg'dan küçük ise, $\mathrm{PaO} 2 / \mathrm{FiO} 2<300$,

- Klinik kötüleşme ile birlikte akciğer grafisi veya tomografide bilateral infiltrasyonlar veya multilober tutulum veya önceki görüntülemesine göre infiltrasyonlarında artış

- Hipotansiyon (sistolik kan basincl $<90$ $\mathrm{mmHg}, \mathrm{OAB}<65 \mathrm{mmHg}$ ) veya vazopressör ihtiyacl

- Ciltte perfüzyon bozuklukları, laktat $>4$ $\mathrm{mmol} / \mathrm{L}$, SOFA skorunda $\geq 2$ birim artış
- Kardiak enzimlerde (Troponin) yükseklik veya aritmi

- Makrofaj Aktivasyon Sendromu bulgularının(lenfosit, trombosit sayılarında düşme, D-dimer, CRP ve ferritin ölçümlerinde yükselme) gelişmesi ${ }^{1-4}$.

\section{COVID-19 Pnömonili Kritik Hastada Klinik, Laboratuvar Ve Görüntüleme Bulguları}

Covid-19 pnömonili kritik hasta karşımıza ciddi pnömoni,ağır solunum yetmezliği ve bașta Akut Solunum Sikıntısı Sendromu (ARDS) olmak üzere sepsisten çoklu organ yetmezliğine kadar tüm organ ve sistemleri tutan bulguların oluşturduğu tablolarla çıkabilir.

Bu hastalarda sıklıkla tip-1 solunum yetmezliğ $i$ görülmekle birlikte, az oranda da tip-2 solunum yetmezliği görülebilir. Ayrıca bu hastalarda kronik kalp, böbrek ve akciğer hastalıklarının akut alevlenmeleride gelişebilir. Bu hastalar yoğun bakımda takip edilmelidirler. Akut Solunum Sıkıntısı Sendromu (ARDS) tanımı: 
» Son bir haftada gelișen veya ağırlașan solunum sıkıntısı

»Görüntülemede plevral efüzyon, kollaps ile açıklanamayan bilateral multilober buzlu cam dansiteleri

» Kalp yetmezliği veya hipervoleminin olmadığı solunum yetmezliği

(transtorasik ekokardiyografi ile sol ventrikül disfonksiyonunun olmadığının gösterilmesi)

(PEEP $\geq 5 \mathrm{cmH} 20$ ) olmakla beraber

» Hafif ARDS: $200<\mathrm{PaO} 2 / \mathrm{FiO} 2 \leq 300$

» Orta ARDS: $100<\mathrm{PaO} 2 / \mathrm{FiO} 2 \leq 200$

» Ağır ARDS: Pa02/FiO2 $\leq 100$

ARDS gelişen hastalarda standart akciğer koruyucu tedavi stratejisi uygulanmalıdır.

Covid-19 pnömonili kritik hastada çoklu organ yetmezliği ve makrofaj aktivasyon sendromu gibi sitokin fırtınasınıda tanımlayacak şekilde geniş laboratuar tetkikleri istenmelidir. Bunlar Tam Kan, CRP, Prokalsitonin, Sedimentasyon, Glukoz, kreatinin, ürik asit, ALT, Total protein, albümin, LD, CK, Na, K, Ca, P, Mg Ferritin Fibrinojen, koagulasyon parametleri, Arteriyel kan gazı, D-dimer ve CK-MB ile hs-Troponin I çalışılmalıdır. Bu tetkikler hasta yattığı sürece düzenli olarak her gün istenmeli ve gelișen değişkenlikler zamanında tespit edilerek gerekli müdahale yapılmalıdır.

Covid-19 pnömonili kritik hastanın radyolojik bulgularını şöyle tanımlayabiliriz. Viral pnömoninin tipik bulguları olan bilateral diffüz buzlu cam görünümünde konsolidasyon ile

birlikte olan veya olmayan infiltratif alanlar, plevral efüzyon olabilir veya olmayabilir ve bulgular genellikle periferdedir ve ters halo işareti gösterir. PA AC grafisi \%30-60 duyarlılıkta olup bilateral orta alt zonları daha çok tutan düşük dansiteli pnömoni odakları (viral pnömoni) görülür 5 .Thoraks tomografide ise Buzlu cam görünümü, konsolidasyon, kaldırım taşı görünümü, hava bronkogramı, vasküler genişleme, bronş değişiklikleri, iki tarafll, periferal ve dorsal, daha çok orta ve alt zonlarda, multilober olma eğiliminde ve peribronkovasküler dağılımda olabilir6 ${ }^{6}$

\section{Entübe Olmayan Kritik Hastada Oksijen Tedavi Yöntemleri}

COVID-19 hastalarında hipoksemi, solunum yetmezliği, septik şok, ARDS varlığında solunum destek tedavisi gerekir. Yoğun Bakıma kabul edilen Covid-19 pnömonili kritik hastanın oksijen saturasyonunu > \% 93 ve üzerindeki değerlere getirebilmek için basitten komplekse doğru çeşitli yöntemler önerilmektedir. $\mathrm{Bu}$ solunum destek tedavileri; geleneksel oksijen tedavisi (Nazal kanül, yüz maskesi, rezervuarlı maske), High flow nasal cannulation(Yüksek akımlı nazal kanulasyon) ve Non-invazif mekanik ventilasyondur. Hangi hastada hangi yöntemi uygulayacağımıza hastanın kliniği ve laboratuar değerleri belirler. Ancak bu tedaviler aerosol oluşumunu artırabildiği için, nozokomiyal yayılım için de risk oluşturmaktadır. $\mathrm{Bu}$ nedenle oksijen ve solunum destek tedavilerinin doğru hastada, doğru önlemler altında uygulanması gerekmektedir. Geleneksel oksijen destek tedavi yöntemleriyle fayda görmeyen hastayı bekletmeden entübe etmek önemlidir. Şimdi sırayla bu yöntemlere kısaca değinelim.

Geleneksel Oksijen tedavisi: düşük akım $(<15$ $\mathrm{L} / \mathrm{dk}$ ) yöntemlerle veya yüksek akıml nazal kanül ile amaç oksijen saturasyonunu \%92'nin üzerinde tutmaktır. Nazal kanülle $6 \mathrm{lt} / \mathrm{dk}$ oksijen ve ulaşllan FiO2 \% 45'i geçmez. 6 L/dk üzeri oksijen ihtiyacı olan hastalarda sırası ile basit yüz maskesiyle $5-8 \quad \mathrm{Lt} / \mathrm{dk} \quad$ oksijen uygulanır. Ulaşılan FiO2 en fazla \%60. Tekrarsolumasız (valfli) rezervuarlı (torbalı) maske 10-15 L/dk akım hızı ile > \%85 FiO2 elde edilir. $>6$ saat, $\mathrm{FiO}^{2}>\% 60$ uygulamak oksijen toksisitesine yol açabilir. $\mathrm{Bu}$ yöntemlerle oksijenizasyonun düzeltilemediği durumlarda; 
- Yüksek akımlı nazal kanül sistemi ile mümkünse akımı arttırıp (en fazla $60 \mathrm{~L} / \mathrm{dk}$ ),

- FiO2 < \% 60 olması sağlanacak şekilde oksijen uygulaması yapılır. Solunum yollarında ölü boşluğu azaltarak, düşük seviyelerde ekspirasyon sonu pozitif basınç (PEEP) sağlayarak solunum iş yükünü azaltır. Yapılan çalışmalarda hipoksemik solunum yetmezliğinde entübasyon ve mortalite oranlarını azalttığı gösterilmiştir ${ }^{7,8}$. Yüksek akımlı nazal kanulasyon ile oksijen uygulamanın aerosol oluşturma riskinden dolayı mümkünse negatif basınçlı odalarda, yok ise tek kişilik odalarda maksimum Kişisel Koruyucu Ekipman ile uygulanması gereklidir. $\mathrm{Bu}$ tedavilerin etkinliği ve etkililiği aşağıdaki parametrelerle izlenmelidir. Oksijen tedavisi alan hastaların izlenmesi;

- 02 Saturasyonu • Solunum sayısı • Dispne • Ek solunum kaslarının kullanılması • Solunum derinliği.

- Gerektikçe arteryel kan gazı. Bu parametrelerle izlenirken hedef değerlere ulaşılmadiysa ve

hastanın hemen entübasyon ihtiyacı yok ise, Noninvaziv mekanik ventilasyon (NIMV) başlanmalıdır. Non-invaziv mekanik ventilatörler, yüze ya da buruna oturan bir maske aracılığı ile pozitif havayolu basınçlarının uygulandığı solunum destek sistemleridir. CPAP ve BPAP uygulanabilir. Hasta bu basınçlar altında spontan solumaya devam eder. Uygulanan cihazın tipine bağlı olmakla birlikte \%100'e kadar artan FiO2 sağlanabilmektedir ${ }^{9,10}$.

Yoğun Bakım ventilatörleri ile NIMV uygulaniyorsa UYARI: Devrelerin inspirasyon ve expirasyon çıkışlarına viral/bakteriyel filtreler eklenmelidir. Hasta klinik kötüleşme açısından yakın takip edilmelidir. İlk bir kaç saatte olumlu yanıt alınamamışsa ve aşağıdaki parametreler gelişmişse; • refrakter hipoksemi, - takipne, • tidal volüm $>9 \mathrm{ml} /$ ideal $\mathrm{kg}$ hiç vakit kaybetmeden, invaziv mekanik ventilasyon açısından değerlendirilmelidir.

\section{Ayrıca aşağıdaki durumlarda NIMV uygulaması yapılmamalıdır;}

Kontrol edilemeyen sekresyonlar, aspirasyon riski, bozuk hemodinami, multiorgan yetmezliği bozulmuş mental durum.

NIMV'nun aerosol oluşturma riskinden dolayı; mümkünse negatif basınçlı odalarda yoksa,

tek kişilik odalarda maksimum kişisel koruyucu ekipman ile uygulama yapılmalıdır.

Hastalara NIMV uygulanırken beraberinde aşağıdaki tedavilerde düşünülmelidir.

* Henüz antiviral tedavi almamışsa Favipiravir tb rehbere göre başlanır.

* Oksijen destek tedavisi alanlara deksametazon ampul 1x1(toplam 10 gün) başlanır.

* Kontrendikasyon yoksa günlük 16 saat (4'er saatlik periyodlar halinde) prone pozisyonu uygulanir

* Endikasyonu olan hastalarda sitokin firtınası için anti-sitokin tedavi seçenekleri IL-6 reseptör antagonisti, IL1-R antagonisti, IVIG ve mezenkimal kök hücre gibi tedavi modaliteleri kullanılabilir.

* Hiperpireksi hızla kontrol edilmeli. Kültürler alınmalı, yeterli ve etkin antibiyotik ve antipiretik tedavi uygulanmalıdır.

* Hipovolemi varsa yeterli sıvı tedavisi ile övolemi sağlanmalıdır,

* Hiperkoagulabiliteyi önlemek için antikoagulan ve antiagregan tedavi başlanmalıdır.

* Hastalar günlük bol proteinli(1,2$1,5 \mathrm{gr} / \mathrm{kg} /$ gün protein) diyetle beslenmelidir ${ }^{11,12}$. 
ENTÜBE OLAN KRITTIK HASTADA SOLUNUM DESTEK TEDAVİSI

Şayet yeteri kadar oksijen destek tedavisi yapılmasına rağmen hedef oksijen saturasyonu, solunum sayısı ve optimal solunum fizyolojisine ulaşılamadıysa bu durumda vakit kaybetmeden entübasyon ile mekanik ventilasyon destek tedavisi düşünülmelidir. Bunun için aşağıdaki kriteler gözönüne alınmalıdır.

- Dispne, • Takipne ( $\geq 30 / \mathrm{dk}), \cdot$ Ek solunum kaslarının kullanımı, • Paradoksik solunum,

- Respiratuvar alkaloz (PaCO2 <35 mmHg, $\mathrm{pH}>$ 7.45)

\section{Endotrakeal entübasyon;}

- Eğitimli ve tecrübeli kişilerce • Hızlı ardışık entübasyon protokolü ile • Mümkünse video laringoskop ile - Zor havayolu olan hastalarda fleksible bronkoskopi eşliğinde • Entübasyonun aerosol oluşturma riskinden dolayı mümkünse negatif basınçlı odalarda, yoksa tek kişilik odalarda maksimum kişisel koruyucu ekipman ile uygulama yapılmalıdır.

Preoksijenizasyon esnasında

- Mümkünse balon-maske kullanma • Kullanılacaksa filtre kullan

Entübasyon öncesi

• Öksürüğü baskılamak için nöromuskuler(NM) bloker kullanilır.

- Endotrakeal kaf şişirilmeden, pozitif basınçlı ventilasyona başlanmamalıdır.

- Isı-nem değiștirici (nemlendirici) filtre kullanılır.
-Yoğun tıkaç ve ölü boşluk artışı durumlarında aktif nemlendirme uygulanır.

- Endikasyon olmadıkça mekanik ventilatör devresinde bağlantı kesilmemelidir.

- Kesilmesi gerekliyse mutlaka kişisel koruyucu ekipman kullanılır.

- Yapılabiliniyorsa kapalı sistem aspirasyon yöntemi uygulanır.

- Bronkodilatör tedavide ölçülü doz inhaler kullanılır.

Covid-19 pnömonili kritik hastalardan, özellikle ARDS gelișen hastalarda akciğer koruyucu mekanik ventilasyon tedavisi özenle uygulanmalıdır. Bunun için volüm kontrollü mod ile volütravmayı azaltmak için $6 \mathrm{ml} /$ ideal kg olarak başlanılmalı, plato basınç $<30 \mathrm{cmH} 20$ ve Pplato basinci(Pplato-PEEP) $<14 \mathrm{cmH} 20$ olmalıdır. Basınçlar yüksek ise $4 \mathrm{ml} / \mathrm{kg}^{\prime}$ a doğru tidal volümler azaltılabilir, ciddi asidoz $(\mathrm{pH}>7,20)$ varsa $8 \mathrm{ml} / \mathrm{kg}^{\prime}$ a çıkılabilir PaO2 6085 mmHg, SaO2 \%88-95 olması kabul edilir ${ }^{13}$. Hiperkapnik seyreden, hasta-ventilatör uyumsuzluğu olan, solunum dürtüsü fazla hastalarda basınçlar yükselmiyor ise 7-8

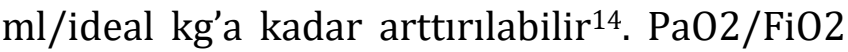
$<150$ olursa ilk 24 saat içinde sedo-analjezi yanında nöromusküler bloker ilaç verilebilir, ancak rutinde önerilmemektedir. PEEP değeri ARDS net tablosuna göre veya en iyi oksijenizasyon ve statik kompliyans değerine göre belirlenmektedir. Statik kompliyansı iyi ( $>40 \mathrm{ml} / \mathrm{cmH} 20$ ) olan hafif ARDS'de düşük PEEP, obez hastalarda, komplians düşük ise ve orta-ağır ARDS'de yüksek PEEP uygulanabilir (Tablo 1$)^{15}$. 
ARDS network PEEP protokolü:

Lower PEEP/Higher $\mathrm{F}_{\mathrm{IO}_{2}}$

$\begin{array}{lllllllllllllll}\mathrm{F}_{\mathrm{IO}_{2}} & 0.3 & 0.4 & 0.4 & 0.5 & 0.5 & 0.6 & 0.7 & 0.7 & 0.7 & 0.8 & 0.9 & 0.9 & 0.9 & 1.0 \\ \mathrm{PEEP} & 5 & 5 & 8 & 8 & 10 & 10 & 10 & 12 & 14 & 14 & 14 & 16 & 18 & 18-24\end{array}$

Higher PEEP/Lower $\mathrm{F}_{\mathrm{IO}_{2}}$

$\begin{array}{llllllllllllllll}\mathrm{F}_{\mathrm{IO}_{2}} & 0.3 & 0.3 & 0.3 & 0.3 & 0.3 & 0.4 & 0.4 & 0.5 & 0.5 & 0.5-0.8 & 0.8 & 0.9 & 0.9 & 1.0 & 1.0 \\ \mathrm{PEEP} & 5 & 8 & 10 & 12 & 14 & 14 & 16 & 16 & 18 & 20 & 22 & 22 & 22 & 22 & 24\end{array}$

020rta-ağır derecede ARDS nedeniyle mekanik ventilatörlerde izlenen hastalarda ihtiyaç

duyulduğunda aralıklı NM bloker bolusları sürekli infüzyona tercih edilmelidir. Persistan ventilatör dissenkronisi, pron ventilasyon veya yüksek plato basıncı durumunda 48 saate kadar sürekli NM bloker uygulaması gerçekleştirilebilir.

Orta-ağır ARDS olgularında $(\mathrm{PaO} 2 / \mathrm{FiO} 2<150)$ günlük 12-16 saat pron pozisyonda ventilasyon uygulanması önerilir.

Doku hipoperfüzyon bulguları, şok tablosu yoksa konservatif sıvı desteği verilmesi önerilir.

Açılama: Pulmoner ödemi azaltmak için sıvı dengesini ayarlamak önemlidir. Şok tablosu yoksa konservatif sıvı tedavisi önerilir; $500 \mathrm{ml}$ 1lt negatifte kalınması önerilir. Şok durumunda özellikle akut böbrek hasarı ve oligüri varlığında sıvı dengesi renal replasman tedavisi ile birlikte sağlanabilir.

Atelekto travmaları engelleyecek ve alveolleri açık tutacak ancak aşırı gerilme yapmayacak basınçlarda PEEP titrasyonu uygulanması önerilir ${ }^{16}$. Orta / ağır ARDS hastalarında yüksek PEEP uygulaması önerilir $(>10 \mathrm{cmH} 20$ PEEP uygulanan hastalar barotravma açısından takip edilmelidir). Eğer hipoksemi derinleşir, PaO2/FiO2 oran $<100-150$ mmHg olursa; PEEP 2-3 cm H20 15-30 dk.da bir artırilır ve 02 Sat \%88-90 aralığında tutulmaya çalıșlır; plato basincl $<30 \mathrm{cmH} 20$ tutulma hedefine dikkat edilir. Optimal ventilasyona rağmen hipoksemisi devam eden COVID-19 ARDS hastalarında rekruitment manevraları denenebilir. Rekuritment manevraları genellikle çok başarılı değildir ama orta dereceli basınçlar, yaklaşık $30 \mathrm{cmH20}$, 20-30 sn süre, ile uygulanabilir, bu sürede hemodinami yakın monitörize edilir. Ĕ̆er hastanın oksijenizasyonunda veya sürücü basıncında düzelme yoksa, hastada hipotansiyon veya barotravma gelişirse rekruitment manevralarına son verilmelidir. Akciğer koruyucu mekanik ventilasyon tedavisine rağmen dirençli hipoksemisi olan hastalarda ekstrakorporeal membran oksijeniasyon(ECMO)desteği

düşünülebilir,uygun hastaların ancak deneyimli merkezlere sevki sağlanabilir ${ }^{17,18}$.

\section{ENTÜBE OLAN KRITTIK HASTADA WEANING SÜRECI}

Weaning süreci sonunda gerçekleşecek olan ekstübasyon işlemi yüksek riskli aerosol oluşturan işlem kapsamında değerlendirilmektedir. Bu yüzden bu işlemin negatif basınçlı odada maksimum kişisel koruyucu ekipman kullanılarak yapılması önerilmektedir.

Şu an için Covid-19 hastalarına özgün bir weaning protokolü tanımlanmamıştır. Hastalar uygun olduğunda standart weaning süreci uygulanmalıdır. Hipoksemik solunum yetmezliğinde NIMV tedavilerinin etkisi sinırlı olmasından dolayı re-entübasyon riski 
açısından ekstübasyon kararı için acele edilmemelidir.

\section{Weaning süreci;}

Önce hastanın ekstübasyona hazır olup olmadığı spontan solunum denemeleri (SSD) ile değerlendirilir.

SSD için T-parçası yerine, kapalı sistem devre (5-8 cmH2O basınç desteği) kullanılır.

Virüs aerosolizasyonu açısından yüksek akımlı oksijen ve NIMV tedavileri riskli olabileceğin den bu hastalar ekstübasyon başarısızlığı açısından yakın takip edilmelidir.

Kaf kaçak testi sadece yüksek riskli hastalarda (entübasyon $>6$ gün, yaş $>80$, geniş endotrakeal tüp, travmatik entübasyon) mümkünse negatif basınçlı odada yapılabilir.

Ekstübasyon mümkünse negatif basınçlı izole odada yapılmalıdır. Personel aerosol oluşturan işlem riskine uygun olarak kişisel koruyucu ekipman (N95 veya eşdeğeri maske, eldiven, gözlük/yüz koruyucu ekipman, bone, önlük) giymelidir.

Ekstübasyon sonrası hastaya oksijen nazal kanül ile, üzerine tıbbi maske de takılarak uygulanmalıdır.

Yüksek riskli aerosol oluşturan bir işlem olması nedeniyle trakeostomi için acele edilmemeli ve her hasta özelinde değerlendirilmelidir. Hasta nonenfeksiyöz olduktan sonra viral bulaştırıcllğ̆ ortadan kalkıp sadece ventilatör ihtiyacı devam ediyorsa ve iyileşme sürecinin on günlük süreyi aşacağı düşünülüyorsa bu durumda planlamalıdır ${ }^{18}$.

\section{PROGNOZ}

Covid-19 pnömonili kritik hastanın prognozunu temelde esas olarak hastalığın Akciğerde tutulum yaygınlığı ile buna eşlik eden akciğer dışı organ tutulumları, yaşı ve şiddetli ARDS varlığ ile mekanik Ventilatör ihtiyacı olup olmadığı belirler. Bunların dışında;
- Eşlik eden hastalıklar (ör. kronik kalp ve akciğer hastalıkları, hipertansiyon, diyabet, kronik böbrek hastalığı)

- İnflamasyon veya pıhtılaşma belirteçleri (ör. D-dimer seviyesi> 1 mikrog / mL, yüksek fibrin yıkım ürünleri, uzamış APTT ve PTZ)

- Lenfopeninin derinleşmesi, nötrofili, troponin artışı diğer faktörler arasında

yer almaktadır. Ölüm oranı hastalığın şiddetine göre \%25-50 arasında değişmektedir ${ }^{19}$.

Çıkar Çatışması Beyanı: Yazarlar çıkar çatışması olmadığını bildirmişlerdir.

Finansal Destek: Bu çalışma her hangi bir fon tarafından desteklenmemiştir.

Declaration of ConflictingInterests: The authors declare that they have no conflict of interest.

Financial Disclosure: No financial support was received.

\section{KAYNAKLAR}

1. T.C. Sağlık Bakanlığı Halk Sağlığı Genel Müdürlüğü COVID-19 (SARS-CoV-2 Enfeksiyonu) Rehberi (Bilim kurulu çalışması), 14 Nisan 2020. https://covid19bilgi.saglik.gov.tr 2.

2. Alhazzani W, Møller MH, Arabi YM, et al. Surviving Sepsis Campaign: guidelines on the management of critically ill adults with Coronavirus Disease 2019 (COVID 19.) Intensive Care Med 2020; 1-34.

3. Jason Phua, Li Weng, Lowell Ling, et al. Intensive care management of coronavirus disease 2019 (COVID-19): challenges and recommendations Lancet Respir Med 2020; S2213-2600(20)30161-2.

4. Pascarella G, Strumia A, Piliego C, et al. COVID-19 diagnosis and management: a comprehensive review. J Intern Med. 2020 Aug;288(2):192-206. doi: 10.1111/joim.13091. Epub 2020 May 13.

5. Chest Radiographic and CT Findings of the 2019 Novel Coronavirus Disease (COVID-19): Analysis of 
Nine Patients Treated in Korea. Yoon SH et al. Korean J Radiol. 2020 Apr; 21: 494-500.

6. Chest CT manifestations of new coronavirus disease 2019 (COVID-19): a pictorial review. Zheng y et al. European Radiology 2020.

7. Ou X, Hua Y, Liu j, Gong C, zhao W. Effect of highflow nasal cannula oxygen therapy in adults with acute hypoxemic respiratory failure: a metaanalysis of randomized controlled trials. $\mathrm{CmAj}$. 2017; 189: E260-E7.

8. Ni YN, Luo j, Yu H, et al. The effect of high-flow nasal cannula in reducing the mortality and the rate of endotracheal intubation when used before mechanical ventilation compared with conventional oxygen therapy and noninvasive positive pressure ventilation. A systematic review and meta-analysis. American journal of Emergency medicine. 2018; 36: 226-33.

9. NHs. specialty guides for patient management during the coronavirus pandemic: Guidance for the role and use of non-invasive respiratory support in adult patients with COVID19. Version: 36 April 2020.

10. Rochwerg B, Brochard L, Elliott mW, et al. Official ERs/ATs clinical practice guidelines:

noninvasive ventilation for acute respiratory failure. Eur Respir j 2017; 50.

11. T.C. Sağlık Bakanlığı Halk Sağlığı Genel Müdürlüğü COVID-19 Hastalarında Destek tedavisi1 (ağır Pnömoni, ARDS, Sepsis ve septik Şok Yönetimi) 21 Nisan 2020. https://covid19bilgi.saglik.gov.tr 12- T.C.Sağlık Bakanlığı Halk Sağlığı Genel Müdürlüğü COVID-19 (SARS-CoV-2 ENFEKSIYONU) ERIŞKIN HASTA
TEDAVİSİ Bilimsel Danışma Kurulu Çalışması 9 EKIM 2020.

13. Fan E, Brodie D, Slutsky AS. Acute Respiratory Distress Syndrome: Advances in Diagnosis and Treatment. jAmA. 2018; 319: 698-710.

14. HALAÇLI B, KAYA A, TOpELİ A. Critically ill COVID19 patient. Turk j med Sci. 2020; 50: 585-91.

15. Thompson BT, Bernard GR. ARDS network (nHLBI) Studies-Successes and Challenges in ARDS Clinical Research. Crit Care Clin. 2011; 27: 459-68.

16. Walkey AJ, Del Sorbo L, Hodgson CL, et al. Higher PEEP versus Lower PEEP Strategies for Patients with Acute Respiratory Distress Syndrome. A Systematic Review and Meta-Analysis. Ann Am Thorac Soc. 2017 Oct;14(Supplement_4): S297S303. doi: 10.1513/AnnalsATS.201704-3380T.

17. Organization WH. Clinical management of severe acute respiratory infection (SARI) when COVID-19 disease is suspected: interim guidance, 2020. https://www.who.int/publications-

detail/clinicalmanagement-of-severe-acuterespiratory---infection-when-novel-coronavirus(ncov)-infection-is-suspected. 18- Anesi GL, Manaker S, Finlay G et al. (2019) Coronavirus disease 2019 (COVID-19): Critical care issues UpToDate. Retrieved April 1, 2020 from; https://www.uptodate. com/ contents /coronavirus-disease-2019- covid-19-critical-careissues.

19.

https://www.uptodate.com/contents/coronavirusdisease-2019-covid-19-critical-care-and-airwaymanagement-issues. 